\title{
Weatherman, the Militant Diagram, and the Problem of Political Passion
}

Nicholas Thoburn

'Mutant' workers in 'veritable wars of subjectivity'; for Félix Guattari, this is what
constitutes the history of the workers' movement. ${ }^{1}$ He has in mind the events
of revolutionary upheaval, the Paris Commune, October 1917 , May 1968. But the problematic of revolutionary subjectivity - in its affective, semiotic, organisational, and imaginary registers - is one that pervades modern socialist, communist and anarchist politics. This problematic is that of the 'militant', of 'militancy', a persistent marker - indeed, often the self-declared guarantor - of radical subjectivity across the spectrum of extra-parliamentary politics. One can think of militancy as a technology of the self, an expression of the working on the self in the service of revolutionary change. However, unlike the subjective correlates of the great revolutionary events, for Guattari this more prosaic aspect of radical practice is not altogether joyful.

This paper is a critique of the militant. ${ }^{2}$ In particular it seeks to understand the ways militancy effectuates political passions and a certain unworking or deterritorialisation of the self in relation to political organisations and the wider social environment within which militants would enact change. To this end the paper traces a 'diagram' or 'abstract machine' of militancy, and considers a particular animation of this diagram in the Weatherman organisation in the United States at the turn of the 1970s. Returning to Marx's concept of the party, the paper then sketches the principle outlines of a counter figure - an 'a-militant diagram', or dispersive ecology of political composition - that suggests a rather different process of subjective unworking.

\section{MILITANT PASSION}

Guattari locates the emergence of the modern militant formation in what he calls the 'Leninist breakthrough' during the 1903 Second Congress of the All-Russian Social Democratic Labour Party, from where - following certain procedural and organisational disputes - emerged a set of affective, semiotic, tactical, and organisational traits that constitute a kind of Leninist diagram or abstract machine. ${ }^{3}$ For Deleuze and Guattari, the diagram or abstract machine is that which governs the articulation and distribution of matter and function in concrete assemblages (where a concrete assemblage may be a carcereal institution, an aesthetic practice, a military technology, an architectural school, and so on). The diagram is not an ideal type, infrastructure or transcendent idea, but a non-unifying immanent cause that is coextensive
1. Félix Guattari, The Guattari Reader, G. Genosko (ed.), London, Blackwell, $1996, \mathrm{p} 124$.

2. A different version of this essay has been published in Ian Buchanan and Nicholas Thoburn (eds), Deleuze and Politics, Edinburgh, Edinburgh University Press, 2008.

3. Félix Guattari, Molecular Revolution: Psychiatry and Politics, R. Sheed (trans.), Harmondsworth, Penguin, 1984, pp 184-95. 
4. Ibid., p190.

5. For a full elaboration of the concept of the diagram as it is used here, see Gilles Deleuze, Foucault, S. Hand (trans.), Minneapolis, University of Minnesota Press, 1988, pp23-44.

6. Ibid., p185, 190.

7. Ibid., p189, 190.

8. Félix Guattari, Chaosophy, S. Lotringer (ed.), New York, Semiotext(e), 1995, p59. with the concrete assemblages that express it. These assemblages, in their divergent manifestations and unexpected conjunctions, in turn feedback into the diagram, both consolidating and modifying its abstract imperatives. As such, even as one sees a regularity of function across its iterations, the diagram is in principle a force of undetermined change, and one existent in a state of disequilibrium.

As a tool of analysis, the concept of the diagram enables one to attend to continuities or resonances across superficially divergent phenomena, and to approach an understanding of the dynamic consistency of arrangements of heterogeneous materials (bodies, signs, images, technologies, affects ...), whilst requiring attention to be paid both to abstract functions and to concrete manifestations as they exist in mutual presupposition. Insofar as the diagram is an abstract entity that is only perceivable through diverse concrete manifestations, the mapping of any diagram is an inexact, tentative, and experimental procedure. It is something like a 'working hypothesis that must be examined with care, re-worked, perhaps even ousted altogether', and is useful only insofar as it brings an appreciation of consistencies, creative processes, points of tension, knots of power, lines of escape, that aid intervention in its field. Of course, any concrete assemblage - including a political grouping - will be governed by more than one diagram. ${ }^{5}$

As to the militant diagram (born in 1903 and consolidated in 'effects of repetition' largely secured by the place of Bolshevism in the 1917 revolution), Guattari argues that it is characterised by: the production of a field of inertia that restricts openness and encourages uncritical acceptance of slogans and doctrine; the hardening of situated statements into universal dogma; the attribution of a messianic vocation to the party; and a domineering and contemptuous attitude - 'that hateful "love" of the militant'- to those known as 'the masses'. ${ }^{6}$ As any diagram, that of the militant draws together its substance in varying ways over time and place, but there is a noticeable regularity of functions upon which, as Guattari wrote in the 1970s, 'our thinking is still largely dependent today': 'From this fundamental breach, then, the Leninist machine was launched on its career; history was still to give it a face and a substance, but its fundamental encoding, so to say, was already determined'. ${ }^{7}$ In discussing the post-' 68 French groupuscule milieu Guattari thus contends that the range of groups from anarchist to Maoist may at once be 'radically opposed in their style: the definition of the leader, of propaganda, a conception of discipline, loyalty, modesty, and the asceticism of the militant', but they essentially perform the same militant function of 'stacking', 'sifting', and 'crushing' desiring energies. ${ }^{8}$

There is, however, a trait of the militant diagram that lacks full articulation in Guattari's presentation, that of passional struggle and its mode of subjective composition. This can be characterised in Deleuze and Guattari's terms as the constitutive 'line of flight' of militancy. Here we need to complicate Guattari's analysis, which chimes with what Deleuze and Guattari will later call the 'signifying regime of signs', with an appreciation of the place within militant formations of the 'passional' and 'subjective' 'postsignifying regime 
of signs'.$^{9}$ In the passional regime, one of a number of semiotic regimes that may be found in any concrete assemblage, the line of flight - the creative or exploratory aspect of an assemblage - takes a singular and dangerous value, operating as the vector upon which subjectivity is at once deterritorialised and intensified. Passional regimes are characterised by 'points of subjectification' that are constituted through the 'betrayal' of dominant social relations and semiotic codes - Deleuze and Guattari offer the example of food for the anorexic - and a certain 'monomania' that, like a 'black hole' of destruction, draws the assemblage through a series of finite linear proceedings, each overcoded by the pursuit of its end, an existence 'under reprieve'. The particular semiotic of the passional regime is composed of a subject of enunciation - a product of the mental reality determined by the point of subjectification - and a subject of the statement, where the latter is bound to the utterances of the former and acts - though the two poles can and do switch places and may be embodied in the same subject - in a 'reductive echolalia' as its respondent or guarantor.

To isolate this passional aspect of militancy requires a turn to an earlier period of Russian agitation, and Sergei Nechaev's 1869 Catechism of the Revolutionist. In the 48 principles that comprise the Catechism, Nechaev outlines an image of revolutionary action, operating through the closed cell of the political organisation, as a singular, all-encompassing passion. It is a cold, calculated passion that, beyond 'romanticism', 'rapture' or 'hatred', requires a dismantling of all relations to self and society that could be conceived of in any manner other than its own furtherance, even at the cost of death:

The revolutionary is a dedicated man. He has no interests of his own, no affairs, no feelings, no attachments, no belongings, not even a name. Everything in him is absorbed by a single exclusive interest, a single thought, a single passion - the revolution ... All the tender and effeminate emotions of kinship, friendship, love, gratitude and even honour must be stifled in him by a cold and single-minded passion for the revolutionary cause ... Night and day he must have but one thought, one aim - merciless destruction. In cold-blooded and tireless pursuit of this aim, he must be prepared both to die himself and destroy with his own hands everything that stands in the way of its achievement ... If he is able to, he must face the annihilation of a situation, of a relationship or of any person who is part of this world - everything and everyone must be equally odious to him. ${ }^{10}$

Given the exemplary misanthropy of Nechaev's text, one might be surprised to find that it has had a persistent presence in radical cultures: Lenin expressed admiration for the tenets of the Catechism; it was until relatively recently accepted as part of the canon of revolutionary anarchism, as a work once thought to have been co-authored with Bakunin; and it was popular amongst, and published and distributed by, the Black Panther Party. ${ }^{11}$ These direct appreciations of the text betray a sense in which its model of passional struggle articulates, albeit in exaggerated form, an enduring property of
9. Gilles Deleuze and Félix Guattari, A Thousand Plateaus: Capitalism and Schizophrenia Volume 2, B. Massumi (trans.), London, Athlone, Ch5.

10. Sergei Nechaev, Catechism of the Revolutionist, $\mathrm{H}$. Sternberg and L. Bott (trans.), London, Violette Nozières Press, 1989, pp4-7.

\section{Luther Blissett} and Stuart Home, Green Apocalypse, London, Unpopular Books, n.d.; David Hilliard and Lewis Cole, This Side of Glory: The Autobiography of David Hilliard and the Story of the Black Panther Party, London, Little, Brown and Company, 1993. 
12. Nina Pelikan

Straus, 'From

Dostoevsky to

Al-Qaeda: What

Fiction Says to Social

Science', Common

Knowledge 12, 2

(2006), pp 197-

213; Sian Sullivan,

"'Viva Nihilism!"

On Militancy

and Machismo in

(Anti-)Globalisation

Protest', CSGR

Working Papers no.

158/05, 2005, www2.

warwick.ac.uk/fac/

soc/csgr/research/

workingpapers/2005/

wp15805.pdf

13. Weatherman emerged from the 1969 position paper 'You Don't Need a Weatherman to Know Which Way the Wind Blows' (a title famously taken from Bob Dylan's 'Subterranean Homesick Blues') as the most militant wing of the anti-Vietnam war movement, initially as a faction within the mass organisation Students for a Democratic Society but soon as an independent and then underground group, when it came to be known as the Weatherman Underground and, later, the genderneutral Weather Underground Organisation, effectively disbanding in 1976. This paper is focused on the brief, preunderground period of Weatherman.

14. Jesse Lemisch, 'Weather Underground Rises the militant diagram. Its presence today, inflected through singular sociohistorical conditions and amidst competing dynamics, is perhaps most apparent in jihadi approaches to struggle, but it can also be detected in left activist cultures, ${ }^{12}$ and may even have some purchase on the popular imaginary - it would, for instance, seem to account for much of the seductive quality of the militant subjectivity constructed in the 2006 film $V$ for Vendetta.

\section{WEATHERMAN}

In order to examine the tangle of militant matters and functions further it is instructive to consider the animation of the militant diagram in a particular political group, or concrete assemblage. The Weatherman organisation is a useful case because of the special emphasis the group placed on the militant transformation of subjectivity, and the way the diagram of militancy here mobilises and draws a consistency from diverse social fields and problematics, notably countercultural styles of living, Maoist approaches to collectivity and struggle, anti-racism, drug use, open sexuality and guerrilla ideology. ${ }^{13}$ That Weatherman is currently the subject of some interest - with the publication since 2000 of a number of critical histories, a collection of communiqués and documents, the memoirs of two key figures, a novel, and an Academy Award-nominated feature documentary - also recommends it, especially since, as Jesse Lemisch notes, there are tendencies in the appreciation of the organisation that would fashion it within a critically unproductive, linear or generational narrative of a generic leftist resistance. ${ }^{14}$ Rather than offering an icon of revolutionary struggle, Weatherman is more useful for the possibility it allows for an exploration of the sometimes highly problematic dynamics and affects that can pass for manifestations of communist subjectivity.

A core trait of the militant machine is the relation it draws between inclusion in the group and commitment to that which characterises the group's uniqueness. In both Guattari's account of the 'field of inertia' of Bolshevism and Nechaev's Catechism, the revolutionary organisation functions as a cut with the social, and as a means to consolidate and intensify its mode of activity, an activity that in turn secures the individual's subjective investment in, and formation through, the organisation. In the case of Weatherman, the mode of activity and the originality of the group was constituted through a particular conception of militant struggle. Framed as anti-imperialist action against the war in Vietnam and the repression of the black community in the US, militancy was characterised by two integrated aspects: the attempt to 'Bring the war home!' under the logic of opening up 'two, three, many Vietnams' in the fabric of US imperialism; and self-sacrifice or betrayal of the white-skin, bourgeois privilege that imperialism conferred on North American whites (including to a large extent the white working class). Militancy thus exhorted a flight away from bourgeois subjectivity toward a becoming with the Vietnamese and US blacks. Yet this was a strange becoming, one not constituted through the drawing of situated relations and projects, but through the mimicry of 
a particular military practice (in what was clearly a very different context to the war situation of Vietnam) and the resultant experience of repression. In discussing Weatherman's 'Days of Rage', Shin'ya Ono expresses something of the kernel of this approach: 'We began to feel the Vietnamese in ourselves. Some of us, at moments, felt we were ready to die'. ${ }^{15}$

Framed in Deleuze and Guattari's terms, this militant sacrifice of the bourgeois self was Weatherman's passional point of subjectification, and offered the vector of its line of flight: 'If you believed something, the proof of that belief was to act on it. It wasn't to espouse it with the right treatises or manifestos. We were militants ... Militancy was the standard by which we measured our aliveness' ${ }^{16}$ This vector was characterised by the impossible limit of truly becoming Americong, of experiencing the full weight of the repression of the US black working class, of fully escaping white subjectivity through militarisation. Militancy thus posed not only a moral standard against which revolutionary vitality and commitment would be assessed, but a kind of 'quasi-spiritual test' (as one pro-situationist critique of Weatherman put it), a test premised on the purification of subjectivity that could only be found through an ever-renewed and -intensified struggle whose limit was constituted ultimately by a preparedness for death. ${ }^{17}$ Such was the force of this vector of militancy that it could be affirmed by Weatherman - in a striking resemblance to Nechaev's image of revolutionary passion, and exemplifying Deleuze and Guattari's understanding of the characteristic delusion of the passional regime - as a monomania. ${ }^{18}$ As Mark Rudd declared at the 1969 Flint 'War Council', the last and somewhat frenzied public gathering of Weatherman before its move underground: 'I'm monomaniacal like Captain Ahab in Moby Dick. He was possessed by one thought: destroying the great white whale. We should be like Captain Ahab and possess one thought - destruction of the mother country' 19

What becomes clear in this articulation is that the efficacy of struggle, the possibility of situated and effective intervention in the social field, is subordinated to, or equated with, the militant construction of subjectivity. Through a betrayal or sacrifice of the bourgeois self, Weatherman came to constitute precisely the self (bolstered through the group subject of the organisation) on its passional line of flight as the locus and guarantor of political truth. This truth was manifest through a set of techniques by which the passion of struggle was played out across the body of the militant.

Most pronounced was the activity, transposed from Chinese Maoism, of collective 'criticism/self-criticism'. In criticism sessions that might last for hours or days, Weather collectives would challenge and confess weaknesses in individual commitments to struggle, tactical mistakes, emotional investments, preparedness for violence, racist inclinations, sexual orientations, aesthetic preferences and so on. Blunt though it could be, criticism was a technology of collective access to, and modulation of, the psychic, cognitive, and affective territories and refrains of the self; put another way, it generated an open field of points of passional betrayal. Sessions could be directed at a particular problem from the Ashes: They're Baack!', New Politics 11, 1 (2006), www.wpunj. edu/newpol/issue41/ Lemisch41.htm

15. Shin'ya Ono, in Harold Jacobs (ed.), Weatherman, Berkeley, Ramparts Press, 1970, p241. Weatherman's 'Days of Rage' action in Chicago in October 1969 aimed at direct physical confrontation with the police and the destruction of property in order to encourage the subjective 'breakthrough' necessary for the establishment of a white revolutionary force.

16. Bill Ayers cited in Jeremy Varon, Bringing the War Home: The Weather Underground, the Red Army Faction, and Revolutionary Violence in the Sixties and Seventies, London, University of California Press, 2004, p87.

17. Point-Blank!, 'The Storms of Youth', Point-Blank!, 1 (1972), 30-41, p36. Weatherman's integration of purity, struggle and sacrifice is especially apparent, and critically attended to, in the autobiography of Cathy Wilkerson, Flying Close to the Sun: My Life and Times as a Weatherman, London, Seven Stories Press, 2007, where she writes: 'The purity of total dedication scraped away many of the complexities of life and promised ultimate gratification. 
Besides, the competitive part of me wanted to be on the best team, the most passionate, the most sacrificing, the most uncompromising, and the most willing to follow each position to the extreme'. Ibid., p293.

18. Weatherman did of course operate in a particular socio-historical environment. If militancy had its own momentum, the horror of the war in Indochina and the brutalisation of black North Americans, most publicly the police assassination of the Black Panther Party's Fred Hampton and Mark Clark, fed Weatherman's passion (in the 2002 documentary film The Weather Underground, Mark Rudd talks of the knowledge of the war as having been 'too great to handle' and something he was aware of 'every second of my life') and was to a considerable extent the guarantor against its consummation.

19. Cited in Ron Jacobs, The Way the Wind Blew: A History of the Weather Underground, London, Verso, 1997, p85.

20. Lowell Dittmer, 'The Structural Evolution of "Criticism and Self-Criticism", The China Quarterly, 56 (1973), 708-729.

21. Susan Stern, With the Weathermen: for the group, but would tend to focus on an individual member, each of whom - important for the weaving of a passional bond - would at different times experience the subject positions of accuser and confessor. Whilst for the Chinese Communist Party, at least in the period before the Cultural Revolution, criticism or 'inner-Party struggle' was primarily a formal procedure for externalising offending acts and developing a redemptive integration of individuals with the organisation,,$^{20}$ in Weatherman criticism took subjectivity directly as its object. The core purpose, as Susan Stern makes clear in her autobiographical account of the Seattle Weather collective, was to break-down and remake the self:

The key to the hours of criticism was struggle ... To purge ourselves of the taint of some twenty-odd years of American indoctrination, we had to tear ourselves apart mentally ... With an enthusiasm born of total commitment we began the impossible task of overhauling our brains ... Turn ourselves inside out and start all over again ... The process of criticism, self-criticism, transformation was the tool by which we would forge ourselves into new human beings. ${ }^{21}$

In accord with the impossible standard of militancy, even the most ferocious criticism could be justified as part of the process of self-transformation. Indeed, as is very clear from Stern's account, a readiness both to enact brutal critique against another and to offer-up in cathartic confession one's worst character traits were markers of revolutionary vitality, a preparedness to live the necessary betrayals of subjectivity and personal attachment that militancy required. Ayers thus describes the process as a 'purifying ceremony involving confession, sacrifice, rebirth, and gratitude'. ${ }^{22}$ The net effect of these sessions was of course that further commitment to struggle and investment in Weatherman was a means to absolve or defer the ever-returning failings of subjectivity that criticism/self-criticism revealed.

This manner of constituting the collective body of the militant had a corresponding mode of sexuality, one characterised by an enforced antimonogamy, the rotation of sexual partners, and group sex, apparently known as 'wargasm'. Whilst anti-monogamy had an important role in feminist and countercultural critique of patriarchal relations and domestic structures, its expression in Weatherman's militancy was such that its dominant function was to counteract the detrimental effects that monogamy could present to the intensification of collectivity. ${ }^{23}$ 'If monogamy was smashed, so the theory went, everyone would love each other equally, and not love some people more than others. If everyone loved each other equally, then they could trust everyone more completely'. ${ }^{24}$ Stern frames collectivity here in terms of 'love', but she is especially attentive to the way that monogamy was seen as an obstacle to the full pursuit of criticism/self-criticism - the principle constitutive field of Weatherman's desire - such that the critique of monogamy was a common focus for these sessions; Stern recounts an occasion where a monogamous couple were subject to two days of criticism after having been encouraged to ingest LSD. ${ }^{25}$ 
Other techniques for the self-constitution of militant investment in action included the 'gut check', the practice of psyching-up oneself and others in a readiness to face or commit violence as an overcoming of perceived cowardice, racism, privilege, or lack of revolutionary commitment in the face of the continued oppression and death of US black peoples and the Vietnamese. It was in such moments of subjective 'breakthrough', experienced as an immanence with the foundational violence of capitalist society, that Weatherman found a kind of revelatory truth, one that marked the 'exemplary' position of the organisation in pushing beyond what they saw as the left's fearbound and half-hearted opposition that served to pre-empt its own defeat. ${ }^{26}$ Something of the orientation of the gut check - or its extreme variant, the 'death trip' - is evident in Ono's account of the Days of Rage:

We frankly told people that, while a massacre was highly unlikely, we expected the actions to be very, very heavy, that hundreds of people might well be arrested and/or hurt, and, finally, that a few people might get killed. We argued that twenty white people (one per cent of the projected minimum) getting killed while fighting hard against imperialist targets would not be a defeat, but a political victory ... ${ }^{27}$

Militancy also plays out through linguistic and symbolic form. As I noted above, for Guattari the signifying regime of Bolshevism is characterised by the transformation of the situated statements of central figures and organisational bodies into dogma and stereotypical formulae, whose repetition as refrains of the organisation function as dominant utterances to construct a field of authority and police divergence. It is a phenomenon clearly evident in Ayers's assessment: 'We began to speak mostly in proverbs from Che or Ho. Soon all we heard in the collectives was an echo'. ${ }^{28}$ The reduction of political language to dogma is aided by, and contributes to, the relation that the militant diagram draws between theory and action. It is on this axis that the passional semiotic can take hold, a semiotic that is 'active rather than ideational', functioning 'more as effort or action than imagination'. ${ }^{29}$ Rather than critical reflection and conceptual production being seen as a constitutive part of practical engagement with the world, struggle tends to be presented in a dichotomous relation to thought - 'Mere words ... mere ideas'. ${ }^{30}$ The possibility of struggle informed by and inflected through thought is thus passed by in favour of an affirmation of the importance of 'doing something'. But once this division is established, language and theory (in the mode of cliché and dogma) can now flip over to the other side of the dichotomy to circulate in a reductive echolalia as so many postulates or 'concise formulae' in the intensification of struggle. ${ }^{31}$

Deleuze and Guattari are attentive here to the place of the word and a certain monotheism of the book - 'the strangest cult' - in the postsignifying regime of signs, as the book becomes the body of passion, extracted from its outside, elevated from critique, and entwined with subjective flight. ${ }^{32}$ This militant trait is most apparent in the Cultural Revolution, where 'Mao Zedong the Personal Journal of a Revolutionary Woman, Garden City NY, Doubleday and Company, 1975, pp94, 96.

22. Bill Ayers, Fugitive Days: A Memoir, Boston, Beacon Press, 2001, p154.

23. It is clear that feminism had a complex and important presence in the organisation and that the 1970 s guerrilla more widely had a strong feminist component - fascinating on this point are the interviews with female members of the Red Brigades conducted by Alison Jamieson, 'Mafiosi and Terrorists: Italian Women in Violent Organizations', SAIS Review, 20, 2 (2000), pp51-64. My argument is that the militant diagram articulates feminist and other political and cultural elements in a manner that tends to further its own imperatives, albeit that these elements so articulated will also have progressive effects for women in militant groups and on the margins of core militant functions.

24. Stern op. cit., p114.

25. Ibid., p197.

26. Ono op. cit., p254.

27. Ibid., p251

28. Ayers, op.cit., p156. 


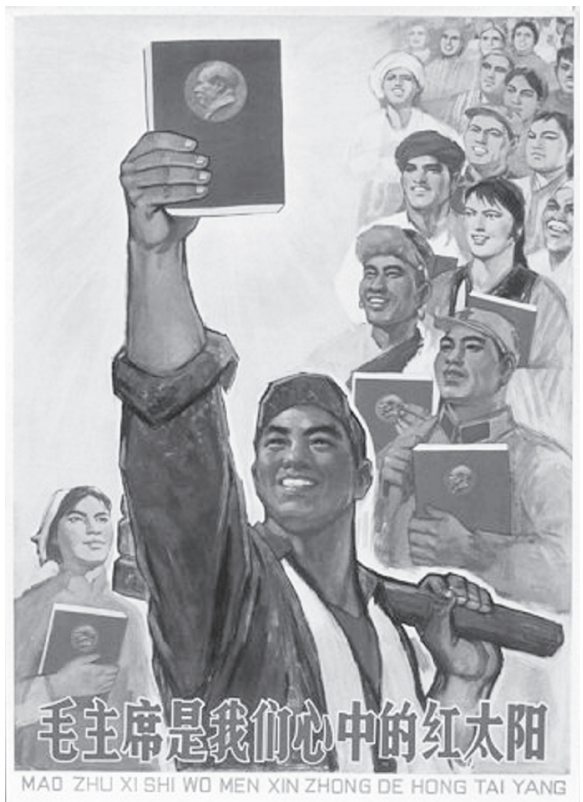

Thought' - articulated as a cosmic truth and embodied most characteristically in the 'Little Red Book' of quotations - had a clear function as immortal substance, nourishment, and energiser of a passional struggle that was to transcend individual mortality. In the words of a 1966 People's Liberation Army newspaper, 'The thought of Mao Tse-tung is the sun in our heart, is the root of our life, is the source of all our strength. Through this, man becomes unselfish, daring, intelligent, able to do everything; he is not conquered by any difficulty and can conquer every enemy' (see Figure 1). ${ }^{33}$

Weatherman was of course a rather different entity from the Cultural Revolution, and constructed little of the latter's highly complex vectoral semiotic components. Nonetheless, the organisation was keenly aware of the militant power of words, even

29. Deleuze and Guattari op. cit., pp124, 120.

30. Ono, cited in Varon op. cit., p89.

31. Deleuze and Guattari op. cit., p120.

32. Op. cit., p127.

33. Cited in Robert Jay Lifton, Revolutionary Immortality: Mao Tsetung and the Chinese if the language now seems only shrill and bombastic. Jeremy Varon draws attention to this aspect of Weatherman, suggesting that: 'Its crude talk of vilifying "pig Amerika”, triumphant slogans, and speeches like those made at the Days of Rage all aimed at strengthening the resolve of its members to use militant action to accomplish what words alone could not'. ${ }^{34}$ Moreover, he argues that Weatherman text and image - in particular its aesthetic forms of collage and cartoon - worked to 'de-realize', and so accelerate, the group's confrontation with the state.

This mode of militant semiotics, then, is not confined to words, but subtends gesture, tone and image. As Guattari argues, 'It's a whole axiomatics, down to the phonological level - the way of articulating certain words, the gesture that accompanies them'. ${ }^{35}$ It is thus possible to perceive the militant semiotic of Weatherman in operation not only within, for instance, Bernardine Dohrn's infamous invocation of the Tate-LaBianca murders by the Manson gang - 'Dig it; first they killed those pigs, then they ate dinner in the room with them, then they shoved a fork into pig Tate's stomach. Wild!'36 - but also in the deployment of images of Ho Chi Minh and the North Vietnamese flag, the posture held at the rostrum, the hard-hat worn at militant actions and disseminated as an iconic image of Weatherman's extremism - even, if one allows for unintended co-production with the

Figure 2. Quarter section of an FBI Weatherman poster 
FBI, in the faciality (the field of eyes like so many passional black holes ${ }^{37}$ ) of the widely distributed 'Wanted' posters (see Figure 2).

It is on this plane of sign and image that the seductive aspect of a militant group like Weatherman is most manifest in wider environments. The composition and circulation of images, styles, sentiments and gestures is certainly a key element in the affective texture of all political milieux. In this context, and drawing a relation to the US group that was most influential on Weatherman and its self-representation, Guattari's comments on Genet's account in Prisoner of Love of the 'image function' of the Black Panther Party are instructive. ${ }^{38}$ In Guattari's reading, the style and comportment of the Panthers created a rich enunciative texture and psychic formation that had especial generative power for black communities in politicising cultural and phenotypical traits, and in developing an experimental image and practice - myths as 'collective operators' - of black resistance and cultural expression, whilst simultaneously haunting and disquieting majority Whiteness (Figure 3). Though of considerably less significance than the BPP, and working with a rather different repertoire of styles and stratifications, the image function of Weatherman (the 'Weather-myth' as it was known) also worked to compose an imaginary and affective field of resistance to US imperialism - and one patterned and inflected by a wider pop- and counter-cultural set of forms and vocabularies - that could have been constitutive of progressive political effects beyond those determined by Weatherman's particular practice.

\section{Figure 3. Kathleen Cleaver and other Black Panthers in the office of the Prosecution} against Huey P. Newton, 1968 @ Bancroft Library, University of California.

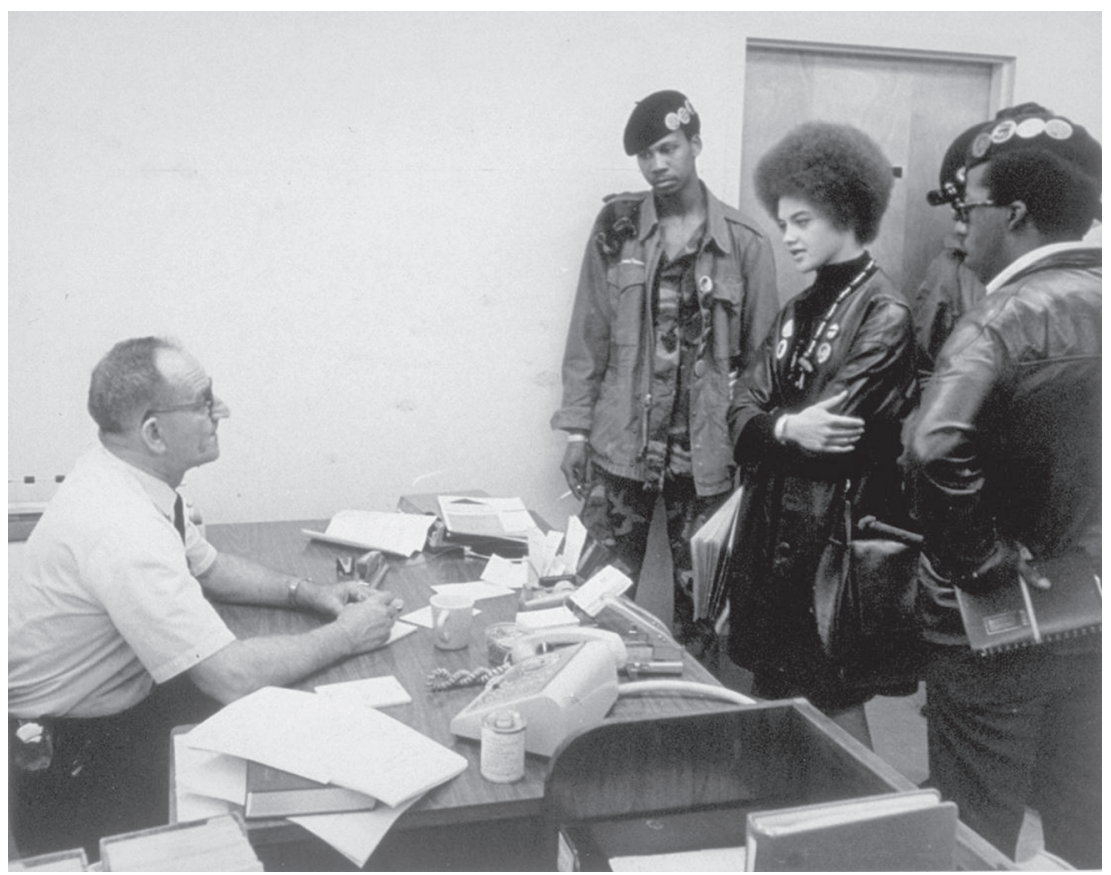

Cultural Revolution, Harmondsworth, Penguin Books, 1970, p72.

34. Op. cit., p89.

35. Op. cit. 1995, p58.

36. Dohrn, cited in Varon op. cit., p160.

37. Deleuze and Guattari, op. cit., pp167-91.

38. Op. cit., 1996, pp218-30. 
39. James Carr, $B A D$ : The Autobiography of James Carr, London, Pelagian Press, 1975; Erika Doss " Revolutionary Art Is a Tool for Liberation": Emory Douglas and Protest Aesthetics at the Black Panther', in Kathleen Cleaver and George Katsiaficas (eds), Liberation, Imagination, and the Black Panther Party, London, Routledge, 2001.
In raising this possibility, however, it is important to be attentive to the way such images can produce a spectacle of revolution that is easily commodified by - or co-produced with - news media and culture industries, and consumed in the politically unproductive manner of an imaginary identification with an icon of resistance. This would seem to have been a prominent feature of the cultural appreciation of the 1970s guerrilla, whether as an alienable unit of consumer style in the 'Prada-Meinhof' mode or, as Bruce LaBruce irreverently dramatises in the queer porn film The Raspberry Reich, a repertoire of radical postures (Figure 4). Whilst it is possible to unsettle or exceed spectacular forms of circulation and consumption - media modulation is certainly more complex than a simple game of resistance and recuperation - one still needs to be careful that the affective charge that may emerge from engagement with these images does not reproduce the militant moods and functions latent in them; even in the existential richness and political intensity of the Panthers' iconography there was interwoven a rather suspect militarised and patriarchal image of militancy. ${ }^{39}$

Figure 4. Bruce LaBruce, The Raspberry Reich, 2004 (C) Peccadillo Pictures/Jürgen

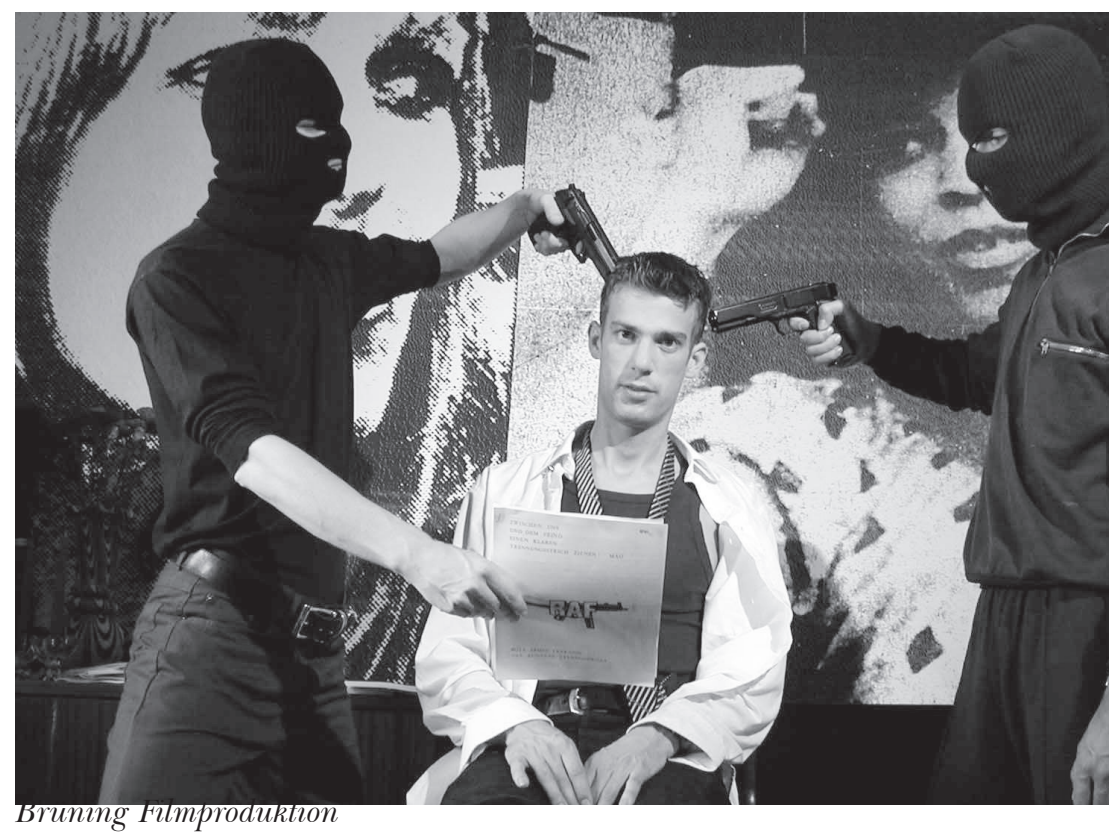

It is a central paradox of militancy that as an organisation constitutes itself as a unified body it tends to become closed to the outside, to the nonmilitant, those who would be the basis of any mass movement. Indeed, to the degree that the militant body conceives of itself as having discovered the correct revolutionary principle and establishes its centre of activity on adherence to this principle, it has a tendency to develop hostility to those who fall short of its standard. Weatherman resolved this paradox by investing 
revolutionary agency in the anti-imperialist struggles of the global South, most prominently that of the Vietcong, and the movements of black revolutionary struggle in 'the internal colony', especially the Black Panther Party. In this arena of agency, the substitution of Weatherman's own exemplary action for a domestic white working-class movement freed it up to exist in splendid isolation and in contempt for the mass of white America. ${ }^{40}$

Ultimately cut off from the possibility of engaging with wider social strata by these techniques, Weatherman was driven into the logical extension of an intensified militancy closed in upon itself, and developed 'the politics of full alienation' (as one member put it to Stern, in the affirmative) in the movement to a clandestine, underground organisation: 'Going underground was not just a wild gambit for me. It was all that was left before death'. ${ }^{41}$ Ayers characterises the build up to this phase of the organisation in a fashion that foregrounds the self-devouring tendencies of militant passion (albeit in a reflection coloured by the New York townhouse bombing ${ }^{42}$ that was to act as something of a break in Weatherman's militant line of flight):

It was fanatical obedience, we militant nonconformists suddenly tripping over one another to be exactly alike, following the sticky rules of congealed idealism. I cannot reproduce the stifling atmosphere that overpowered us. Events came together with the gentleness of an impending train wreck, and there was the sad sensation of waiting for impact. ${ }^{43}$

\section{CONTOURS OF AN A-MILITANT DIAGRAM}

In order to approach the possibility of a political practice beyond militancy I want in the remainder of this paper to consider some initial contours of an a-militant diagram, or dispersive ecology of composition. To do this I will confine the discussion to the relation between the political group and that which lies outside it, what might be known by militant assemblages as 'the masses' - as Guattari implies, it is on this axis that the question of an 'other machine' beyond that of the militant should be posed. ${ }^{44}$ It is instructive to address this question through Marx's problematic of the party.

Given the dominant twentieth-century image of political Marxism, The Manifesto of the Communist Party has very little to do with the kind of party one might expect. It sets up a 'Manifesto of the party itself' to counter the bourgeois 'nursery tale of the Spectre of Communism', but the party is not announced as a distinct (much less, timeless) organisational entity:

The Communists do not form a separate party opposed to other working-class parties.

They have no interests separate and apart from those of the proletariat as a whole.

They do not set up any sectarian principles of their own, by which to shape and mould the proletarian movement. 
45. Karl Marx and Friedrich Engels, The Revolutions of 1848: Political Writings Volume 1, ed. D. Fernbach, Harmondsworth, Penguin, 1973, pp79, 98.

46. Alain Badiou, 'Politics Unbound', in Metapolitics, J. Barker (trans.), London, Verso, 2005, pp74, 75.

47. Karl Marx, Grundrisse: Foundations of the Critique of Political Economy (Rough Draft), M. Nicolaus (trans.), Harmondsworth, Penguin, 1973, p692.

\section{Jacques} Rancière, The Philosopher and His Poor, J. Drury, C. Oster, and A. Parker (trans.), London, Duke University Press, 2003, p86.

49. Nicholas Thoburn, Deleuze, Marx and Politics, London, Routledge, 2003, Ch3.
The Communists are distinguished from the other working-class parties by this only:

1. In the national struggles of the proletarians of the different countries, they point out and bring to the front the common interests of the entire proletariat, independently of all nationality.

2. In the various stages of development which the struggle of the working class against the bourgeoisie has to pass through, they always and everywhere represent the interests of the movement as a whole. ${ }^{45}$

If not an organisational entity, the party instead suggests a diagram of composition, a virtual set of parameters and orientations, and one that is immanent to 'the proletariat as a whole'. Though the party seeks to forward certain modes of thought and community - notably, internationalism and the critique of capital - Marx is at pains to stress that it is not a concentrative articulation, but a dispersive one. The party is stretched across the social, dependent upon social forces and struggles for its existence or its substance, and, in an anticipatory and precarious fashion, oriented toward social contingencies and events. As Alain Badiou argues - if to use his work in this context is not to deform it too far - not only is it the case that 'For the Marx of 1848, that which is named "party" has no form of bond even in the institutional sense', but 'the real characteristic of the party is not its firmness, but its porosity to the event, its dispersive flexibility in the face of unforeseeable circumstances' ${ }^{46}$ To this should be added that, inasmuch as the party is immanent to the manifold arrangements of capitalist social production, a production that is fully machinic ('this automaton consisting of numerous mechanical and intellectual organs'), it poses a terrain of alliance and event that exceeds an abstract humanity. ${ }^{47}$

Given the precarious and anticipatory orientation of the party, there is considerable insight in Jacques Rancière's argument that Marx's party - for all its universality - is directed not toward unity but division, that 'first of all the purpose of a party is not to unite but divide'. ${ }^{48}$ In Rancière's reading of Marx, this division names the communist disruption of the modes of identity and security associated with the workers' movement; one could say that it is the effect of the proletariat as its own overcoming on the workers' movement as identity. ${ }^{49}$ Yet Rancière reduces this process of disruption to a mechanism of interminable deferral on Marx's part, a mechanism that induces Marx's dissolution of the Communist League and thereafter sets up the science of capital, and the writing of its book, as the proxy of the proletariat forever postponed. In making 'division' function in Marx as a selfseparation from politics, Rancière both elides the fundamental innovation of Marx's dispersive understanding of the party and ignores the dynamic and intensive facets of its division in the practical critique of authoritarian and anti-proletarian organisational practice - vis-à-vis, for instance, the persistence of Freemasonry and the secret society in the workers' movement, Jacobin models of dictatorship by enlightened minority, utopian efforts to bypass 
the working class, Bakuninist 'invisible dictatorship', and so on.

Jacques Camatte and Gianni Collu’s 1969 open letter 'On Organization' (which marked the withdrawal of the group around the journal Invariance from the post-' 68 groupuscule milieu and their dissolution as an organised body) approaches Marx's party in a more productive fashion than Rancière. ${ }^{50}$ In the left communist tradition with which Camatte is associated, the variable nature of struggle over time and the complexity of forces and problems that make up any historical conjuncture are such that there is no necessary continuity of a 'formal' party. ${ }^{51}$ Indeed, in times when agitation is on the wane, attempts to constitute revolutionary organisations become counterproductive, not least because they substitute organisational coherence and continuity for diffuse social struggle as the object of communist politics (this, as part of maintaining global conditions conducive for the survival of the Soviet economy, having been a key effect of the Communist Party on the international stage). As such, in François Martin's assessment, 'The dissolution of the organizational forms which are created by the movement, and which disappear when the movement ends, does not reflect the weakness of the movement, but rather its strength' ${ }^{52}$

Camatte and Collu extend this position to argue that all radical organisations tend toward a counter-revolutionary, 'racket' form, functioning as anti-inventive points of attraction and solidification in social environments. In a critique that bears comparison with Guattari's account of Bolshevism, Camatte and Collu argue that the radical group is the political correlate of the modern business organisation, orchestrating patterns of identity and investment appropriate to a capitalism that - in what is an early use of the concept of 'real subsumption' - has disarticulated sociality from traditional forms of community and identity and incorporated the workers' movement in its own dynamic. Operating through a foundational and ever-renewed demarcation between interior and exterior, the group coheres through the attraction points of theoretical or activist standpoint and key members (themselves constituted as such through intellectual sophistication, militant commitment or charismatic personality), and the motive forces of membership prestige, competition for recognition and fear of exclusion. The effect is to reproduce in militants the psychological dependencies, hierarchies and competitive traits of the wider society, constitute an homogeneous formation based on the equivalence of its members to the particular element that defines it, and mark a delimiting separation from - and, ultimately, a hostility to - the open manifold of social relations and struggles, precisely that which should be the milieu of inventive communist politics. Importantly, the problem is not at all one of the relative formality of the group; these tendencies may well be found at the extreme in 'unstructured' aggregations or 'disorganisations', where informal inter-subjective relations take primacy. ${ }^{53}$

Some of these aspects of militant group-formation have been seen above in Weatherman, but the pertinent point here is the way Camatte and Collu seek to develop a way out from the organisation. In opposition to the centripetal dynamics of the group-form and its militant subjective correlate, Camatte and

50. Jacques Camatte and Gianni Collu, 'On Organization', Edizioni

International (trans.), in Jacques Camatte, This World We Must Leave and Other Essays, A. Trotter (ed.), New York, Autonomedia, 1995, pp19-38.

51. See Karl Marx, 'Marx to Ferdinand Freiligrath, February 29 1860', n.d., www. marxists.org/archive/ marx/works/1860/ letters/60_02 29.htm, where against the accusation of 'inactivity' and 'doctrinaire indifference' he positively evaluates his non-involvement in political associations in the period after the collapse of the Communist League; and Jacques Camatte, Origin and Function of the Party Form, n.d., www. geocities.com/ Cordobakaf/camatte_ origins.html

52. In Gilles Dauvé and François Martin, The Eclipse and Re-emergence of the Communist Movement (revised edition), London, Antagonism Press, n.d., p57.

53. Jo Freeman, The Tyranny of Structurelessness, London, Anarchist Workers Association, n.d.; Andrew X,

'Give Up Activism', Reflections on June 18, no publisher given, 1999; J. J. King, 'The Packet Gang', Mute 27, 2004, www. metamute.com/look/ article.tpl?IdLangua ge $=1 \&$ IdPublication $=1 \&$ NrIssue $=27 \& \mathrm{~N}$ rSection $=10 \& \mathrm{NrArti}$ cle $=962$ 
54. Cited in Camatte and Collu op. cit., p20.

55. Ibid., pp32-3.

56. Dauvé and Martin, op. cit., p63-76.

57. Jérémie Valentin, 'Gilles Deleuze's Political Posture', C. V. Boundas and S. Lamble (trans.), in C. V. Boundas (ed.), Deleuze and Philosophy, Edinburgh, Edinburgh University Press, 2006; Ian Buchanan and Nicholas Thoburn, 'Introduction', op. cit.

58. In Gilles Deleuze and Félix Guattari, AntiOedipus: Capitalism and Schizophrenia Volume 1, R. Hurley, M. Seem and $H$. R. Lane (trans.), London, Athlone, 1983, pxii.
Collu assert that communist practice is necessarily characterised by a refusal of all group activity, a kind of warding-off of the dominant social tendency toward group formation. This critique of the group is not followed with an assertion of individual subjectivity - a locus of composition no less able to accrue prestige and authority in opposition to dispersive social struggle. Indeed, the critique of the group has a corresponding subjective unworking in the 'revolutionary anonymity' that Camatte and Collu borrow from Amadeo Bordiga, as signalled by their text's epigraph from Marx: 'Both of us scoff at being popular. Among other things our disgust at any personality cult is evidence of this ... When Engels and I first joined the secret society of communists, we did it on the condition sine qua non that they repeal all statutes that would be favourable to a cult of authority. ${ }^{54}$ In place of the group and the individual, the basis of composition instead becomes an immanence with social forces: 'The revolutionary must not identify himself [sic] with a group but recognize himself in a theory that does not depend on a group or on a review, because it is the expression of an existing class struggle. ${ }^{55}$

Camatte and Collu's anti-voluntarist subtraction of agency from communist minorities is an intriguing and important articulation of Marx's dispersive and disruptive party. But as it plays out in line with a common dilemma for left communist groupings - whose opposition to the Leninist party can result in a reluctance to engage in any form of intervention for fear of directly or indirectly introducing anti-inventive dynamics and leadership models into proletarian formations $^{56}$ - it offers only a partial solution to the problem of militancy. Outside a period of agitation, Camatte and Collu leave communist minorities in a rather anaemic position, without a positive conception of the field of political composition other than the development of theory and the maintenance of a small network of informal relations between those engaged in similar work.

Deleuze and Guattari's approach to the question of the group and its outside shares much with that of Camatte and Collu, not least in their own ‘involuntarism' - a crucial mechanism in opening a breach with received political practice, identity and authority, and orienting toward the event. ${ }^{57}$ But out of this shared problematic emerges a more productive sense of the terrain of a-militant composition. In his preface to Anti-Oedipus Foucault rightly draws attention to the way the book invited a practical critique of militant organisations and subjectivities:

I would say that Anti-Oedipus (may its authors forgive me) is a book of ethics, the first book of ethics to be written in France in quite a long time (perhaps that explains why its success was not limited to a particular 'readership': being anti-oedipal has become a life style, a way of thinking and living). How does one keep from being fascist, even (especially) when one believes oneself to be a revolutionary militant? ${ }^{58}$

Unlike Camatte and Collu, however, this practical critique of militancy is characterised not by a withdrawal from groups as such. It initially takes the 
form of an analytic of groups and a certain affirmation of the 'subject group' as a mode of political composition oriented toward innovative collective composition and enunciation, and open to its outside and the possibility of its own death - in contrast to the 'subjected group', cut off from the world and fixated on its own self-preservation. ${ }^{59}$ Yet this formulation, useful though it is in the analysis of group dynamics, is perhaps still too caught up with activist patterns of collectivity and voluntarism. As Deleuze and Guattari's project unfolds, the model of the subject group thus loses prominence in favour of an opening of perception to, and critical engagement with, the multiplicity of groups - or, in Deleuze and Guattari's terms, assemblages or arrangements - which compose any situation, following their notion that 'we are all groupuscules'. Guattari thus states in a 1980 interview:

At one time I came up with the idea of the 'subject-group'. I contrasted these with 'subjected groups' in an attempt to define modes of intervention which I described as micro-political. I've changed my mind: there are no subject-groups, but arrangements of enunciation, of subjectivization, pragmatic arrangements which do not coincide with circumscribed groups. These arrangements can involve individuals but also ways of seeing the world, emotional systems, conceptual machines, memory devices, economic, social components, elements of all kinds. ${ }^{60}$

In this conception there is a clear disarticulation of political practice from the construction of coherent collective subjectivity, or a strong critique of groups, but in a fashion that bypasses the anti-group position with an orientation toward the discontinuous and multi-layered arrangements that traverse and compose social - or, indeed, planetary - life. Crucially, the associated political articulations - 'cartographies' or 'ecologies' in Guattari's later writings - are machinic in nature. They include, and may be instigated by, material and immaterial objects - technological apparatus, medias, city-environments, images, economic instruments, sonorous fields, landscapes, aesthetic artefacts - as much as human bodies, subjective dispositions and cognitive and affective refrains. As such, they are open to political analysis, intervention and modulation through tactical, sensual, linguistic, technical, organisational, architectural and conceptual repertoires. It would certainly be a mistake to see this ecological orientation as a retreat from a passional practice - if Anti-Oedipus suggests an antifascist ethics, $A$ Thousand Plateaus is precisely concerned with the exploration of modes and techniques of passional composition, often of a most experimental and liminal kind. This is a passion, however, that arises not in a subjective monomania carved off from its outside, but from situated problematics that are characterised by a deferral of subjective interiority and a dispersive opening to the social multiplicity and its virtual potential. This is how one can understand Deleuze and Guattari's affirmation of 'becoming imperceptible' - of drawing the world on oneself and oneself on the world - as a political figure; it is not a sublime end-point of spiritual inaction, but the immanent kernel of a-militant political composition. ${ }^{61}$
59. Gilles Deleuze,

'Three GroupRelated Problems', in Desert Islands and Other Texts 19531974, D. Lapoujade (ed.), M. Taormina (trans.), New York, Semiotext(e), 2004, pp193-203.

60. Félix Guattari, Soft Subversions, S. Lotringer (ed.), D. L. Sweet and C. Wiener (trans.), New York, Semiotext(e), 1996, pp227-8.

61. I have approached some of the many subsequent questions about the nature of such composition - not least with regard to the place of capital - through the figure of 'minor politics' in Nicholas Thoburn, op. cit., 2003, and 'The Hobo Anomalous: Class, Minorities and Political Invention in the Industrial Workers of the World', Social Movement Studies 2, 1 (2003), 61-84. 
62. Yann Moulier, 'Introduction', P. Hurd (trans.), in Antoinio Negri, The Politics of Subversion: A Manifesto for the Twenty-First Century, Cambridge, Polity Press, 1989; Bureau d'Études, 'Resymbolising Machines: Art after Oyvind Fahlström', B. Holmes (trans.), Third Text 18, 6 (2004), pp609-16.

63. Colectivo Situaciones, 'Something More on Research Militancy', S. Touza and N. Holdren (trans.), Ephemera: Theory and Politics in Organization 5, 4 (2005), pp602-14.
Given the prominence in twentieth-century political culture of visual images of the heroic militant, it is important to note that aspects of this ecological or cartographic approach can also be seen in the aesthetic expressions of political bodies - from the anecdote that the orientations of Italian Operaismo were such that the bedroom walls of activists saw the substitution of diagrammatic maps of the FIAT Mirafiori plant for the iconic images of Mao and Che Guevara, to Bureau d'Études who, mindful of the dangers of the conventional signs of militant aggregation such as the flag and the raised fist, symmetrical with the images of national sovereignty as they can be, have developed a political and pedagogical ecology routed through the aesthetic and cognitive object of the map (Figure 5). ${ }^{62}$

The exploration of some of these themes is also evident in contemporary problematisation of activist practice. A most striking instance is the Argentinean grouping Colectivo Situaciones, whose figure of 'militant research' evokes a knowledge/practice that works without subject or object through an immanent appreciation of encounters, problems and situations, and in a fashion that is particularly attentive to the dangers of transcendent models of political subjectivity and communication. ${ }^{63}$ The problematic of a dispersive political practice is raised too in the Luther Blissett and Wu Ming projects, concerned as these experiments in the 'multiple name' have been with a disarticulation of

Figure 5. Bureau d'Études 'Infowar/psychic war', utangente.free.fr

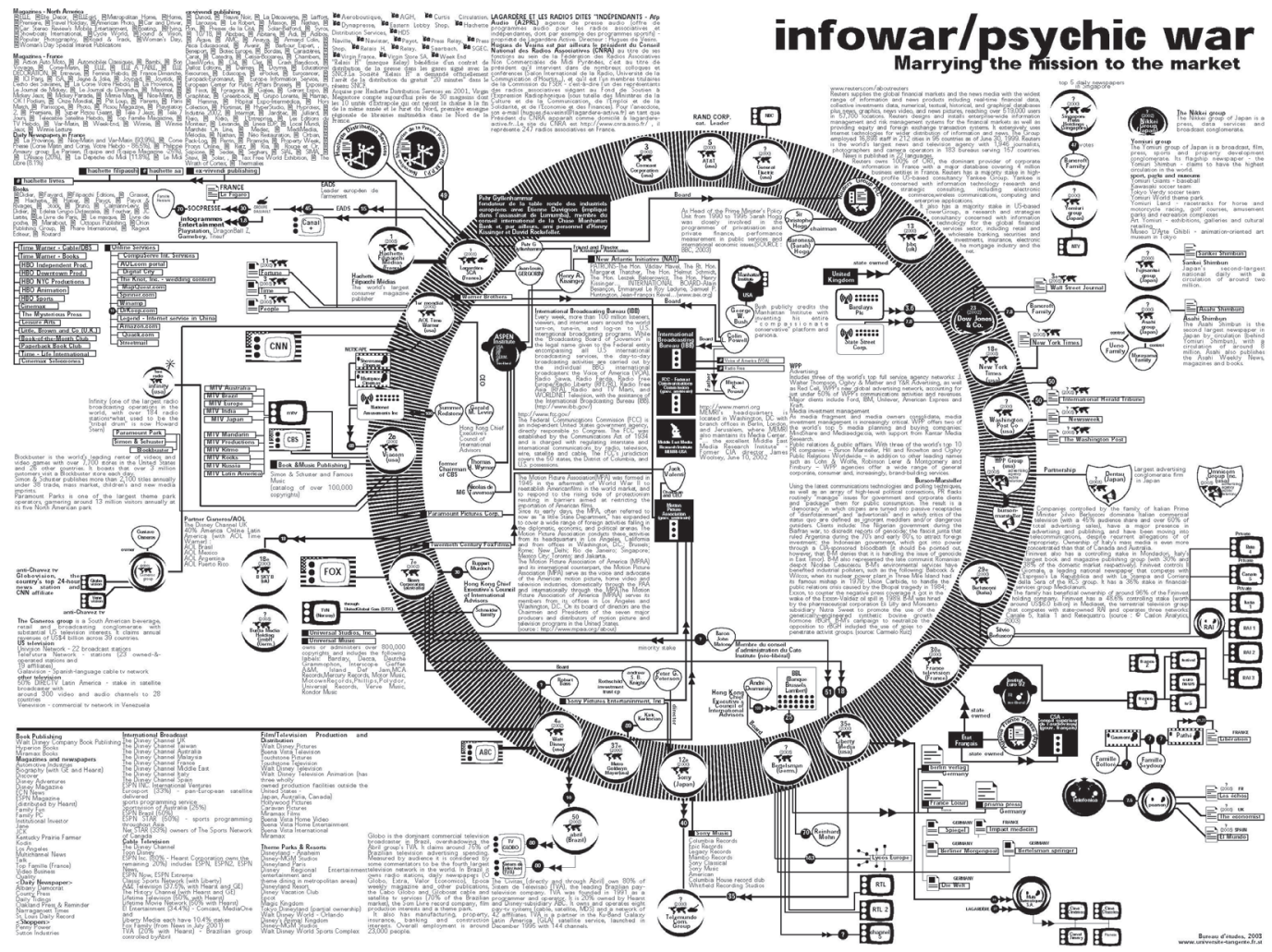


seduction, style and mythopoesis from the author-function and its associated regimes of property and authority - something of a left communist erasure of militant faciality (Figure 6). But these formations lead to questions of composition that are best approached through an appreciation of their particularity, and that move beyond the specific focus of this paper, the critique of the militant.

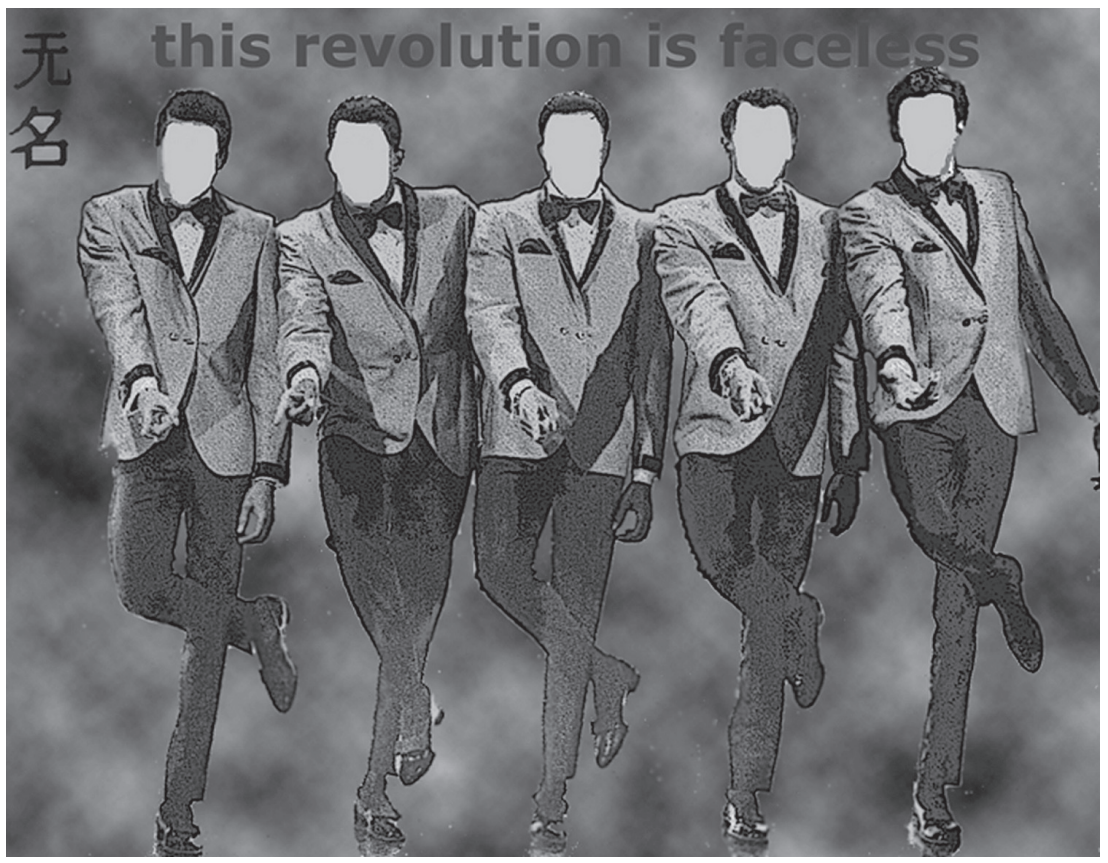

Figure 6. Wu Ming's 'official portrait' 2001-2008, Creative Commons License, en.wikipedia.org/wiki/Wu_Ming

\section{CONCLUSION}

One can discern in Deleuze and Guattari's work an identification of, and a response to, the problem of militant subjectivity. This response posits a deterritorialisation of the self that develops not from a concentration in militant passion (as one finds in Weatherman) or a surrender to revolutionary inaction (the danger that haunts Camatte's critique of organisation), but from the condition of being stretched across the social in a diffusion and critical involution in the technical, aesthetic, semiotic, economic, affective relations of the world. In resonance with Marx's understanding of the party, this suggests not a serene unanimity but a complex, intensive, and open plane of composition. The party here is a field of intervention in social relations that undoes identity, not an identity carved off against social relations.

This is not, of course, an actualised politics or programme; it is better seen as the first principle of an a-militant, communist diagram. The interventions, aggregations, functions and expressions that animate and enrich this diagram may well configure environments of a directly insurrectionary nature, but 
64. Karl Marx and Friedrich Engels, Collected Works Volume 10: 1849-1951,

London, Lawrence and Wishart, 1978, p318.

65. In Gilles Deleuze and Claire Parnet, Dialogues, $\mathrm{H}$. Tomlinson and B. Habberjam (trans.), London, Athlone, 1987, p139. they would be so as the collective and manifold problematisation of social relations and events, not as the invention of militant organisations acting like 'alchemists of the revolution' ${ }^{64}$ For it is in the multiple and diffuse social arrangements and lines of flight that political change emerges and with which political formations - in their 'dispersive flexibility' - need to maintain an intimate and subtle relation if they are not to fall into the calcified selfassurance of militant subjectivity. Deleuze's warning about the danger of marginality has pertinence here too:

It is not the marginals who create the lines; they install themselves on these lines and make them their property, and this is fine when they have that strange modesty of men [sic] of the line, the prudence of the experimenter, but it is a disaster when they slip into the black hole from which they no longer utter anything but the micro-fascist speech of their dependency and their giddiness: 'We are the avant-garde', 'We are the marginals. ${ }^{65}$ 